\title{
Effects of percentage of goal-punished extinction trials on self-punitive behavior
}

\author{
MICHAEL D. MATTHEWS and HAROLD BABB \\ State University of New York at Binghamton, Binghamton, New York 13901
}

\begin{abstract}
Following 20 shock-escape acquisition trials in a straight runway, 36 female albino rats were given .5-sec shock after entering the goalbox on $0 \%, 20 \%, 40 \%, 60 \%, 80 \%$, or $100 \%$ of extinction trials. Relative to the $0 \%$ controls, all punished groups ran significantly faster during extinction but did not differ significantly among themselves. The results confirm earlier studies demonstrating self-punitive behavior using the goal-shock procedure and are consistent with other research in which intermittent punishment has been applied in the alley. Nevertheless, the results do not seem to be supportive of theoretical points of view that stress the critical importance of maintaining the eliciting stimuli and the reinforcing conditions that were present during acquisition.
\end{abstract}

Babb and Hom (1971) and Hom and Babb (1975) demonstrated self-punitive responding in rats using a goal-punishment procedure. Previous studies of selfpunitive behavior failed to obtain the effect using goal punishment (Kintz \& Bruning, 1967; Seligman \& Campbell, 1965), and found less of an effect as punishment was presented nearer the goalbox (Campbell, Smith \& Misanin, 1966; Martin \& Melvin, 1964). These results invited the conclusion that punishment administered in the goalbox would not facilitate responding but would suppress it instead (Fowler, 1971; Melvin, 1971). Mackintosh (1974) states: "The procedure used to establish 'self-punitive' behavior in these experiments can thus be seen to be carefully designed so as to maintain the eliciting stimuli and reinforcing conditions of acquisition. As one would expect from this account, both escape and avoidance responding are facilitated to a greater extent if shock is delivered near the startbox than if it is delivered near the goalbox."

The purpose of the present study was to replicate Babb and Hom's (1971) and Hom and Babb's (1975) basic findings, that is, that rats punished in the goalbox during extinction following escape training in a straight alley would run faster and longer than animals given no shock during extinction. In addition, different percentages of punishment would be administered. Previous studies examining the effects of periodic punishment, which applied punishment in different parts of the alley but not in the goalbox, have yielded mixed results. Several studies (Beecroft, Fisher, \& Bouska, 1967; Gwinn, 1949; Martin \& Moon, 1968) found that rats given different schedules of punished extinction respond similarly to rats given punishment on every extinction trial. In contrast, Bender and Melvin (1967) and Melvin

Requests for reprints should be addressed to Harold Babb, Psychology Department, State University of New York at Binghamton, Binghamton, New York 13901.
(1964) reported that self-punitive behavior was an increasing function of percentage of punished extinction trials. The present study will attempt to clarify this relationship between percent of punished trials and magnitude of self-punitive behavior, and extend the effects of this manipulation to the goal-punishment procedure.

\section{METHOD}

\section{Subjects}

The subjects were 36 female Sprague-Dawley rats obtained from the laboratory's colony room. The animals were experimentally naive and ranged in age from 100 to 120 days at the beginning of the experiment. They were maintained ad lib on standard Purina Laboratory Chow and water over the course of the study.

\section{Apparatus}

The apparatus consisted of a straight runway with an alley $122 \mathrm{~cm}$ long x $15.5 \mathrm{~cm}$ wide, a startbox $30 \mathrm{~cm}$ long $\times 15.5 \mathrm{~cm}$ wide, and a goalbox $30 \mathrm{~cm}$ long $\times 26 \mathrm{~cm}$ wide. The runway was $13 \mathrm{~cm}$ high throughout, contained a stainless steel grid floor in the goalbox as well as in the startbox and runway, was covered with clear Plexiglas, and was a medium gray in color except for the grid floor, and doors, and the ceiling.

The startbox and goalbox were separated from the alley by guillotine doors, and the goalbox was situated $4 \mathrm{~cm}$ from the end of the alley. Both doors were made of clear Plexiglas and were channeled in aluminum frames that abutted $2 \mathrm{~cm}$ into the alley on both sides. The startbox door contained strips of black plastic tape applied horizontally, each with a length of $5 \mathrm{~cm}$ and a height of $2 \mathrm{~cm}$, and each $.5 \mathrm{~cm}$ above the other. The bottom strip was $4 \mathrm{~cm}$ above the grid floor.

Photoelectric beams were situated in the alley, $1 \mathrm{~cm}$ past the startbox door and $1 \mathrm{~cm}$ before the goalbox door, and in the goalbox, $11 \mathrm{~cm}$ past the goalbox door. The grid floor was composed of bars that were $6.3 \mathrm{~cm}$ wide and spaced $6.3 \mathrm{~cm}$ apart. As measured on the grid, shock of $1 \mathrm{~mA}$ was delivered by an Applegate stimulator and a Davis scrambler, with the latter hooked successively to every 18 bars. Latency measures for start time and run time were taken by Textronix TM 503 timers. Other related equipment consisted of Hunter and BRS/LVE timers and relays. 
An Edwards Lungen buzzer (Cat. No. 115-2, $24 \mathrm{~V}$ ac), situated $15 \mathrm{~cm}$ from the end wall of the startbox, rested on soft plastic foam and was attached to the apparatus platform with a rubber strip. The buzzer emitted an 83-dB noise, as measured inside the startbox. The ambient noise level in the box was $54 \mathrm{~dB}$, which partially reflected the fact that the runway and response measuring clocks were situated inside a soundinsulated room while intermittent noise-making portions of the apparatus were on the outside. Noise levels in the runway were measured with a General Radio $1551 \mathrm{C}$ sound-level meter using the $20-\mathrm{kHz}$ scale.

\section{Procedure}

The experiment was a 6 (percent of punishment) by 14 (blocks) design, with six subjects per group, and consisted of three phases: pretraining, acquisition, and extinction. On the 1 st day of pretraining, each rat was handled for $5 \mathrm{~min}$. On the next day, each rat was handled for $2 \mathrm{~min}$ and then placed in a six-chamber retaining cage. After six animals had been placed in the retaining cage, the first animal was removed, handled for $1 \mathrm{~min}$, and replaced in the cage. The procedure was repeated until each animal had been handled and replaced in the retaining cage three times. On the 3rd day of pretraining, each animal was handled for 2 min and placed in the retaining cage; in squads of six, they were then wheeled into the room adjoining the runway, where each was removed and carried into the runway room, through two doors and back, three times. This was done to habituate the rats to the between-trial sequence of events they would encounter during subsequent stages of the experiment. On the 4 th day of pretraining, the animals were again handled for $2 \mathrm{~min}$ and wheeled into the room adjoining the runway. They were then carried individually through the doors into the runway room and were placed in the alley for $2 \mathrm{~min}$ and in the goalbox for $3 \mathrm{~min}$.

Acquisition was initiated on the 5 th day. The animals were run in squads of six and were given five trials a day for 20 days, with an ITI of 6-8 $\mathrm{min}$. In each acquisition session, the first rat was removed from the retaining cage, carried to the runway room, and placed in the startbox. Five seconds later, the gate door was vigorously raised and shock and CS conditions initiated. During acquisition, shock was present in the startbox and alley, but not in the goalbox. While shock was terminated as the animal left the alley, the CS remained on until the photobeam located inside the goalbox was interrupted. The animal was allowed to remain in the goalbox for $30 \mathrm{sec}$. It was then removed to a retaining cage to await its next trial.

For the extinction phase, trials were administered as described above, but no shock was present in the startbox or alley. The animals were randomly divided into six groups of six rats each. The regular extinction (RE) group received no punishment during extinction. The other five groups received goal punishment on $20 \%, 40 \%, 60 \%, 80 \%$, or $100 \%$ of extinction trials. Punished trials were randomly determined within any given extinction block, with the restriction that the first trial of the first extinction session was punished for all punished groups, and no more than two consecutive sessions could consist of the same pattern of punished trials. For all punished trials, $.5 \mathrm{sec}$ of shock was administered $.2 \mathrm{sec}$ after the rat broke the photobeam located in the goalbox. Extinction consisted of 14 five-trial sessions or until a rat reached an extinction criterion defined as a failure to enter the goalbox within $60 \mathrm{sec}$ after the startbox door had been opened. If an animal met that criterion, start and run times of $60 \mathrm{sec}$ were recorded for all remaining trials.

\section{RESULTS AND DISCUSSION}

On the final block of acquisition, the six groups did not differ in run speeds $[F(5,30)=1.0, p>.05]$ or in start speeds $[\mathrm{F}(5,30)=1.2, \mathrm{p}>.05]$, indicating that all groups were performing equivalently at this point.

The main findings of the experiment are presented in Figure 1, which plots run speeds over the 14 blocks of extinction. The RE group dropped off in run speed slowly but steadily, whereas run speeds were maintained at a relatively high rate for all of the punished groups, although the lower percentages of punishment, .20 and .40 , appear to be somewhat slower than the speeds of the other three punished groups. An overall analysis of variance showed significant effects for trial blocks $[F(13,390)=3.51, p<.05]$, and Percent Punishment by Blocks interaction $[F(65,390)=3.72, p<.05]$. Post hoc comparisons, by Duncan's new multiple range test, showed that all punished groups ran significantly faster than the RE group ( $<<.05)$, but did not differ among themselves. Separate analyses of the first seven blocks, the last seven blocks, and the last block yielded identical conclusions.

Figure 2 shows start speeds for the 14 blocks of extinction. Start speeds were more variable than run

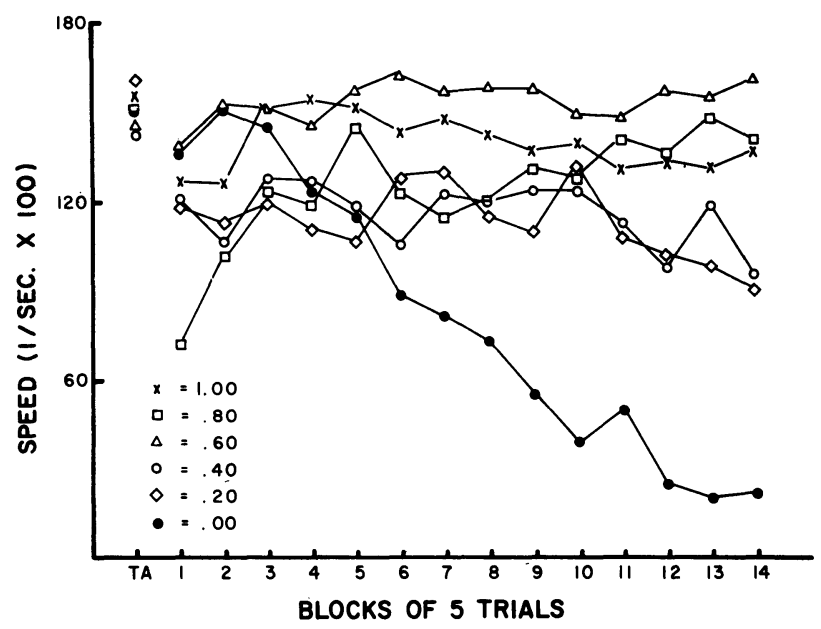

Figure 1. Mean run speeds on the final acquisition block and the 14 blocks of extinction for punished $(20 \%, 40 \%, 60 \%$, $80 \%$, and $100 \%$ ) and nonpunished $(0 \%)$ groups.

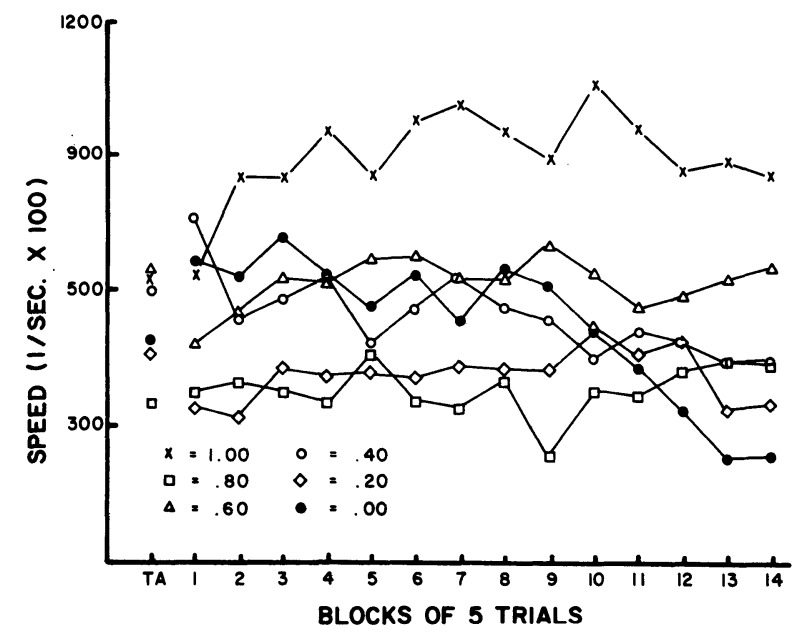

Figure 2. Mean start speeds on the final acquisition block and the 14 blocks of extinction for punished $(20 \%, 40 \%, 60 \%$, $80 \%$, and $100 \%$ ) and nonpunished (0\%) groups. 
speeds, but, with the exception of the .80 punished group, it appears that groups receiving higher percentages of punishment left the startbox faster during extinction than the RE group or groups receiving low percentages of punishment. Indeed, the $100 \%$ punished group started faster than any of the other five groups on all but the first extinction block. An overall analysis of variance showed a significant effect for Blocks by Percent interaction $[F(65,390)=1.40, p<.05]$. Post hoc comparisons by Duncan's new multiple range test showed that the $100 \%$ group started significantly faster than the $20 \%$ and $80 \%$ groups, but there were no further significant differences among the groups. Separate analyses of variance for the first and last seven blocks, and the last block of extinction yielded the same conclusions.

The results of the present study confirm the earlier findings of Babb and Hom (1971) and Hom and Babb (1975), who found that rats punished in the goalbox during extinction ran significantly faster than rats not shocked during extinction. In addition, the data support the findings of Beecroft, Fisher, \& Bouska (1967), Gwinn (1949), and Martin and Moon (1968), who, using an alley shock punishment procedure, found that percent of punished extinction trials had no substantial effects on the magnitude of the self-punitive effect. It may also be noted that, while Melvin (1964) reported extinction run speeds to be an increasing function of percentage of punished trials, the punished groups did not differ significantly among themselves, and only a nonsignificant trend of increased run speed with increased percent of punishment was observed. Thus, the results of the current study, in addition to those of previous relevant studies, allow the conclusion that some minimal number of punished extinction trials is sufficient to produce the self-punitive effect and establish a generality between the goal-shock and alleyshock procedures. Just what minimum number of shocks during extinction may be necessary to produce selfpunitive behavior is not clear, but it must be fairly small, as Bender and Melvin (1967) report that as little as $10 \%$ punished extinction trials is sufficient to maintain self-punitive running.

Start speed data are more difficult to interpret since, as usual, they contain a much larger amount of variability than do the run times. However, it is interesting to note that there was a percent punishment effect on start speeds, with the group punished on every trial starting faster than other groups, but with significance present only in the comparisons between it and the $20 \%$ and $80 \%$ groups. This finding conflicts with the apparent either-or character of the run speed findings; and, together, the results appear to be inconsistent with points of view suggesting that self-punitive responding is principally a matter of maintaining the initial eliciting conditions sufficiently to "trigger" the response. Similarly, since punishment was delivered for a fixed interval of time, the effects cannot be explained by the claim (Mackintosh, 1974) that self-punitive responding is simply a function of the fact that faster running during punishment decreases the amount of shock received. Moreover, the efficient maintenance of responding by punishment presented in the goalbox, like that obtained by Babb and Hom (1971) and Hom and Babb (1975), would seem to diminish the theoretical importance of any hypothetical reinforcement or confirmation "event" that may be presumed to take place at that point in time when the animal leaves the alley and enters the goalbox. Instead, the relative strength of aversive and conditioned aversive events in different parts of the runway may have a greater influence on the behavioral outcome.

\section{REFERENCES}

BABB, H., \& HoM, H. L., JR. Self-punitive behavior with goal shock. Journal of Comparative and Physiological Psychology, 1971, 77, 482-488.

Beecroft, R. S., Fisher, B. G., \& Bouska, S. A. Punishment continuity and self-punitive behavior. Psychonomic Science, 1967, 9, 127-128.

Bender, L., \& Melvin, K. B. Self-punitive behavior: Effects of percentage of punishment on extinction of escape and avoidance responses. Psychonomic Science, 1967, 9, 573-574.

Campbell, B. A., Smith, N. F. S., \& Misanin, J. R. Effects of punishment on extinction of avoidance behavior: Avoidance-avoidance conflict or vicious-circle behavior? Journal of Comparative and Physiological Psychology, 1966, 62, 495-498.

FowLER, H. Suppression and facilitation by response contingent shock. In F. R. Brush (Ed.), Aversive conditioning and learning. New York: Academic Press, 1971. Pp. 537-604.

Gwins, G. T. The effects of punishment on acts motivated by fear. Journal of Experimental Psychology, 1949, 39, 260-269.

Hом, H. L., JR., \& BABB, H. Self-punitive responding in rats with goal shock and color change. Animal Learning \& Behavior, 1975, 3, 152-156.

Kintz, B. L., \& Bruning, J. L. Punishment and compulsive avoidance behavior. Journal of Comparative and Physiological Psychology, 1967, 63, 323-326.

Mackintosh, N. J. The psychology of animal learning. New York: Academic Press, 1974.

Martin, R. C., \& Melvin, K. B. Vicious circle behavior as a function of delay of punishment. Psychonomic Science, 1964, 1, 415-416.

Martin, R. C., \& Moon, T. L. Self-punitive behavior and periodic punishment. Psychonomic Science, 1968, 10, 245-246.

Melvin, K. B. Escape learning and "vicious circle" behavior as a function of percentage of reinforcement. Journal of Comparative and Physiological Psychology, 1964, 58, 248-251.

Melvin, K. B. Vicious circle behavior. In H. D. Kimmel (Ed.), Experimental psychopathology: Recent research and theory. New York: Academic Press, 1971. Pp. 95-115.

Seligman, M. E. P., \& Campbell, B. A. Effect of intensity and duration of punishment on extinction of an avoidance response. Journal of Comparative and Physiological Psychology, 1965, 59, 295-297.

(Received for publication April 6, 1978.) 